\title{
Physical Characteristics of Probiotic Effervescent Tablets with Various Concentration of Maltodextrin as Coating Materials
}

\author{
Devi Ambarwaty Oktavia*, Diini Fithriani and Pujoyuwono Martosuyono \\ Research and Development Center for Marine and Fisheries Product Processing and Biotechnology, \\ Jakarta
}

\begin{abstract}
The application of RICA (Research Institute for Coastal Aquaculture) liquid probiotic bacteria proved to be able to prevent attacks of both types of vibriosis disease and White Spot Syndrome Virus (WSSV) through improved pond water quality. This RICA liquid probiotics is coated using maltodextrin with 3 variations of concentration which are then formed into probiotic effervescent tablets. Apart from making it easy to distribute, this solid probiotic is easily applied without fermentation such as the use of liquid probiotics. The aims of this study was to determine the physical characteristics of probiotic effervescent tablets from maltodextrin coatings with different concentration. The concentration maltodextrin as coating materials were is $20 \%, 30 \%$ and $40 \%(\mathrm{~b} / \mathrm{v})$. The parameters test are average weight, friability, hardness and disintegration time. The results showed that the effervescent tablets of probiotics with a concentration of maltodextrin $40 \%$ had a mean weight higher than other concentrations at $798.88 \mathrm{mg}$. While the effervescent tablets of probiotic with a maltodextrin concentration of $20 \%$ had a lower friability and disintegration time compared to other concentrations of $0.05 \%$ and 12.96 minutes. And has a higher level of hardness that is equal to $10.89 \mathrm{~N}$ compared to other concentrations that is $30 \%$ and $40 \%$ concentration maltodextrin. The concentration of $20 \%$ maltodextrin was the best treatment of this study.
\end{abstract}

\section{Introduction}

The problem faced in the development of shrimp ponds in Indonesia is the tendency to decrease productivity and high shrimp mortality rates, one of the causes is the low quality of pond water [1]. Water as a medium of shrimp life must meet both the quality and quantity

\footnotetext{
*Corresponding author: devi_oktav@yahoo.co.uk
} 
requirements. Pond water management is a water preparation activity to maintain water quality during maintenance, as well as treatment of pond wastewater.

The development of aquaculture in the field of fisheries spurred the development of the use of probiotics [2]. This encourages exploration of natural bacteria from various sources that are potentially used as probiotics and biocontrol. Some sources of probiotic bacteria that have been studied include seawater and marine sediments, corals, hatcheries, leaf mangrove and shrimp farms, from seabream, from catfish intestines, from Tilapia and from fish intestines.

The use of probiotics in enlargement ponds is generally intended to improve water quality, such as decomposing organic matter from leftover feed that is not consumed by shrimp and also by shrimp feces. The higher the feed dosage that is not utilized so that it will pollute the cultivation environment itself. Therefore, probiotics are needed to decompose the remaining feed. Oxygen is one of the water quality variables that can influence other variables and can be influenced by temperature, salinity, organic matter and brightness [3]. Combination of five probiotic bacterial isolates at the same time or in turn could increase survival and production of tiger shrimp in ponds. The composition of the right type of probiotic bacteria is still needed in order to improve pond water quality, so that pathogenic organisms do not develop and the survival of tiger shrimp and its production can increase [4].

The provision of probiotics can also improve water quality, probiotics can also regulate the condition of microorganisms, increase the diversity of microorganisms, improve host health and minimize the effects of pathogenic bacteria. In addition, many uses of probiotics are a parameter of excellence in improving water quality [5]. Effervescent tablets contain acid and carbonate or bicarbonate which react quickly to the addition of water by releasing carbon dioxide [6] The advantage of this dosage form is in terms of preparing the solution in an instant that contains the right dosage of the drug [7]. One of the starch modification products that can be used as a thin film coating (film coating) tablet is maltodextrin [21]. The coating of the tablet aims to mask the taste, odor, unpleasant color of the active substance and which is easily damaged by the outside air. Maltodextrin can be used as an ingredient thin film coating at a concentration of $10-25 \%$. Tablet which is coated with a containing coating material maltodextrin shows better results. In this study, probiotic powder preparations will be studied in the form of effervescent tablets with tablet formulas which have optimum physical properties for application in shrimp farm land.

\section{Material and methods}

\subsection{Preparation probiotic powder}

Liquid probiotics that contain Brevibacillus laterosporus which isolated from ponds were suspended into $20 \%, 30 \%$ and $40 \%$ concentration maltodextrin in $50 \mathrm{ml}$ of water. This suspension was incubated for 30 minutes at $37^{\circ} \mathrm{C}$ with a constant rotation to adapt the mixture before drying. The mixture then dried with spray dryer to obtain probiotic powder. The temperature of the spray dryer inlet is $160^{\circ} \mathrm{C}$ and the outlet is $40^{\circ} \mathrm{C}$ [13].

\subsection{Preparation of effervescent tablets}

To improve flow ability, granules are first made and then added to the effervescent mixture. This research used citric acids as acid source and solubility enhancer, carbonate source using sodium bicarbonate, lactose as filler and magnesium stearate as lubricant [14, 15]. Acid is present in the composition in an amount $10 \%$ by weight to about $60 \%$, more preferably from 
about $25-40 \%$ by weight using stevia. The base is present in the composition in an amount of from $10 \%$ by weight to about $60 \%$ by weight, more preferably from about $15 \%$ by weight to about $50 \%$ by weight [16]. The acid composition that used in this research are $10 \%$ and base composition $40 \%$ by weight. All of the preparation process of the effervescent tablet was done at humidity $\leq 30 \%$ [23].

\subsubsection{Mixing ingredients}

The ingredients used are first mixed evenly at room RH $40 \%$. The process of printing probiotic effervescent tablets uses wet granulation. The way is to separate between acidic materials, namely citric acid and bases, namely sodium bicarbonate.

\subsubsection{Tablet forming}

Tablet forming can be done by compression method [17]. Material that has been mixed with the specified formula is put into the mold, then compressed with a pressing force. Tablet printing uses a mini tablet press machine.

\subsection{Scanning Electron Microscope (SEM)}

Observation by Scanning Electron Microscope (SEM) to determine the structure of maltodextrin powder or effervescent tablet and their size.

\subsection{Physical properties of tablets [18]}

\subsubsection{Average weight}

A total of 10 tablets were weighed randomly using analytical scales (brand MettlerTOLEDO) to determine their average weight; a 5\% deviation was considered acceptable.

\subsubsection{Hardness}

Hardness was measured using a hardness tester (brand Erweka, model TBH-30). The results obtained was the mean of resistance of the 10 tablets and was expressed in Newton (N). The minimum value recommended for hardness is $30 \mathrm{~N}$.

\subsubsection{Friability}

The parameter is determined using a friabilometer (brand Erweka, model TAR). Samples of 10 tablets were submitted to a $25 \mathrm{rpm}$ rotation speed for 4 minutes, a weight loss maximum value of $1 \%$ was considered acceptable.

\subsubsection{Disintegration}

The disintegration time of the six tablets was determined using a disintegration apparatus (brand Erweka, model ZT3) and distilled water at $37 \pm 2^{\circ} \mathrm{C}$ as a disintegration media. Disintegration time limit of 5 minutes is considered acceptable. 


\subsubsection{Data Analysis}

Data and statistics analysis were made by using analysis of variant (one way ANOVA). A value of $\mathrm{p}<0.05$ was considered significant statistically.

\section{Results and discussion}

Based on the calculation of weight uniformity in all probiotic effervescent tablets produced and seen in Figure 1, no tablet has a weight deviating more than $10 \%$ from its average weight. It can be concluded that all probiotic effervescent tablets with all maltodextrin coating concentrations meet the requirements in the Indonesian Pharmacopoeia. Effervescent tablet standards are as follows: maximum hardness of $30 \mathrm{~N}$, maximum hardness of $1 \%$, maximum standard deviation of average weight is $5 \%$ and maximum dissolution time of 30 minutes [22]. The result of statistical analysis using one way ANOVA showed that uniformity of weight (average weight) from all concentration of maltodextrin coatings were significantly different $(\mathrm{p}<0.05)$.

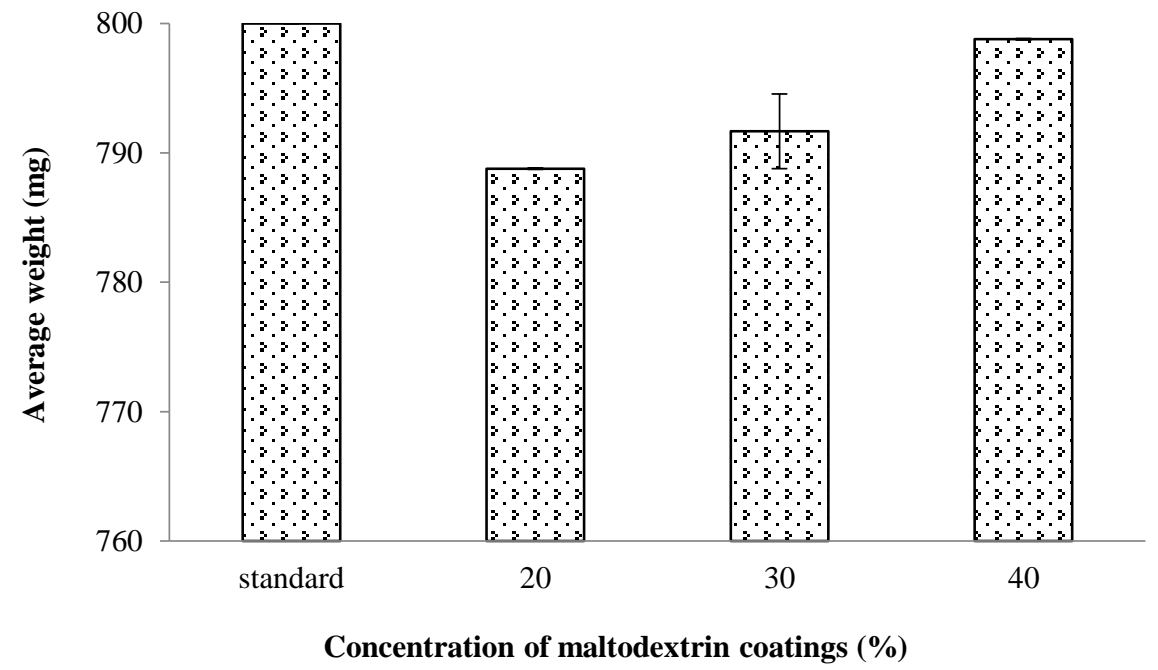

Fig 1. Average weight of probiotic effervescent tablets at several concentrations of maltodextrin coating

Tablet hardness is influenced by several factors including the compressive force used when pressing, the nature of the raw material and the type of adhesive used. Hardness is generally associated with the type and purpose of its use. Low hardness is usually intended for chewable tablets, while high hardness is applied to coated tablets so that they are not damaged when coating [14]. The minimum value recommended for hardness is $30 \mathrm{~N}$. Tablet [18]. Effervescent tablets of probiotics that have been produced are then carried out hardness tests to determine the ability of the tablet to hold the load after printing. The amount of pressure used until the broken tablet shows the resistance of the tablet to withstand the maximum load, which is referred to as tablet hardness. 


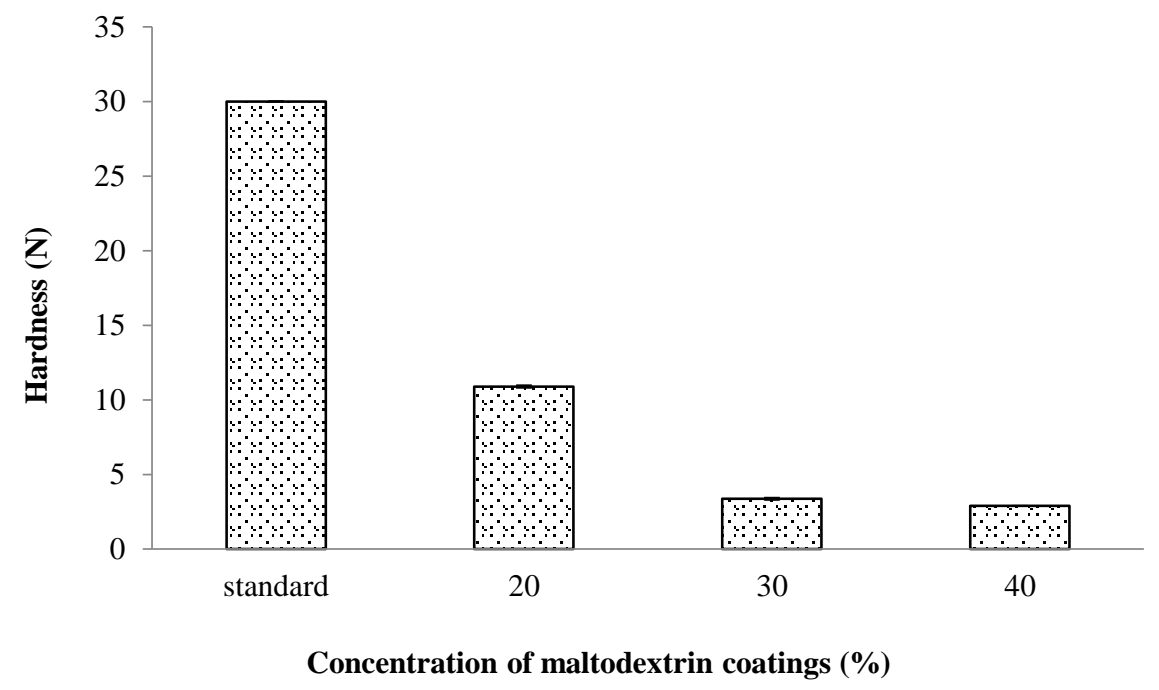

Fig 2. Hardness of probiotic effervescent tablets at several concentrations of maltodextrin coating

Tablet hardness measurement was used as physical quality parameters to determine the compactness of tablets after printing. Tablets that are compact or hard are not easily destroyed during the distribution and storage process. It can be seen from Figure 2 that the probiotic effervescent tablets produced with a concentration of $20 \%$ maltodextrin coating had higher hardness than other concentrations. The concentration of citric acid and sodium bicarbonate greatly influence the hardness of the probiotic effervescent tablets produced. During the pressing process, there is friction between the tangent points of the granular surface so that heat arises which can increase the temperature of the material beyond the glass transition temperature. In this condition. Citric acid will experience melting earlier because it has the lowest glass transition temperature of $31^{\circ} \mathrm{C}$ so that it can function as an adhesive [14]. The result of statistical analysis using one way ANOVA showed that tablet evaluation (hardness) from all concentration of maltodextrin coatings were significantly different $(p<0.05)$.

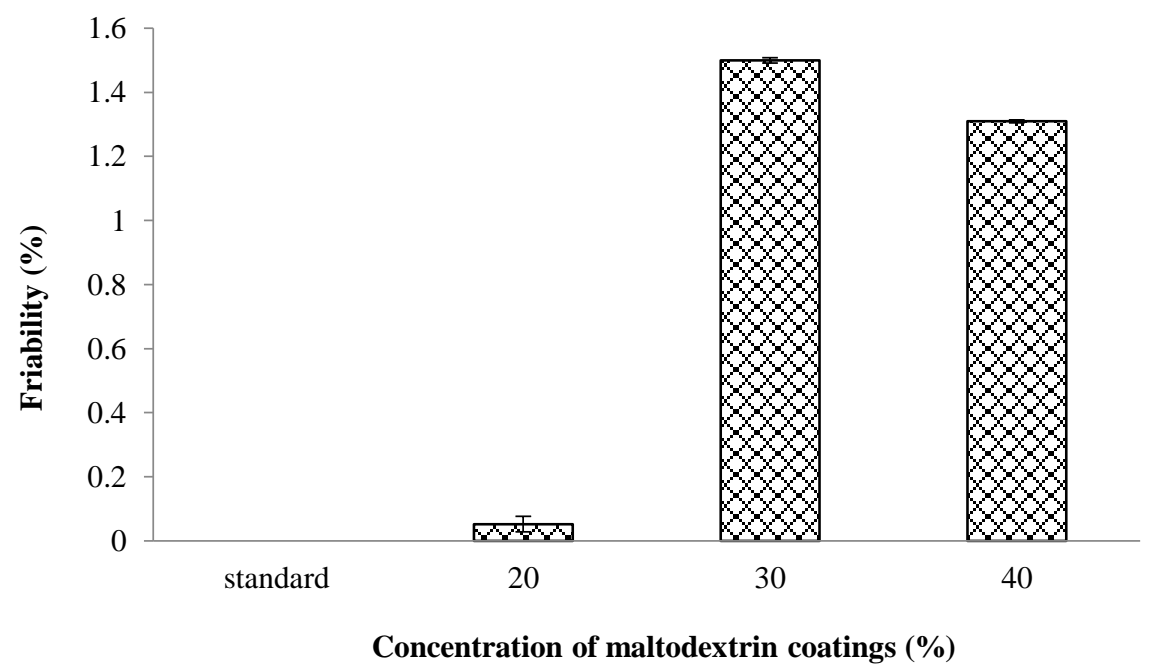

Fig 3. Friability of probiotic effervescent tablets at several concentrations of maltodextrin coating 
Friability testing needs to be done because tablet hardness is not an absolute parameter of tablet strength. Fragility of tablets illustrates the physical strength of the outside of the tablet which has a role in fighting mechanical shocks. A good tablet has a friability value of no more than $1 \%$ [18]. The use of excessive mechanical pressuring energy will produce effervescent tablets that are too hard so it is difficult to dissolve. Conversely, the use of pressing mechanical energy that is too low will result in a fragile tablet. The contradiction between these two properties is a challenge in making effervescent tablets [14]. It can be seen from Figure 3 that the friability of probiotic effervescent tablets with a concentration of $20 \%$ maltodextrin coating is lower than other concentrations. The lower concentration of the maltodextrin coating (20\%) compared to other concentrations $(30 \%$ and $40 \%)$ results in a lower value of friability. Fragile tablets will break easily or if they are too hard cause it is difficult to dissolve. This phenomenon is caused by the determination of formulas and the use of non-optimum pressing forces. Fragile effervescent tablets may easily dissolve, but these tablets are not resistant to mechanical interference during distribution or storage [20]. The result of statistical analysis using one way ANOVA showed that friability from all concentration of maltodextrin coatings were significantly different $(p<0.05)$.

It can be seen from Figure 4 that the disintegration time of probiotic effervescent tablets with $20 \%$ maltodextrin as coating has a faster solubility compared to other concentrations but this solubility is closer to the set standard of 5 minutes. A compact and compact tablet will sink first and then rise to the surface, so the time needed to dissolve completely longer [14]. Fragile tablets will dissolve immediately and break on the surface of the water, so the solubility is relatively faster. In accordance with the results of this study that brittle tablets usually have a shorter dissolving time. The high pressing force causes the density of the tablet to be smaller, so that the penetration of liquid into the tablet structure becomes difficult. This greatly affects the solubility of the tablet [19]. The result of statistical analysis using one way ANOVA showed that tablet evaluation (disintegration time) from all concentration of maltodextrin coatings were significantly different $(\mathrm{p}<0.05)$.

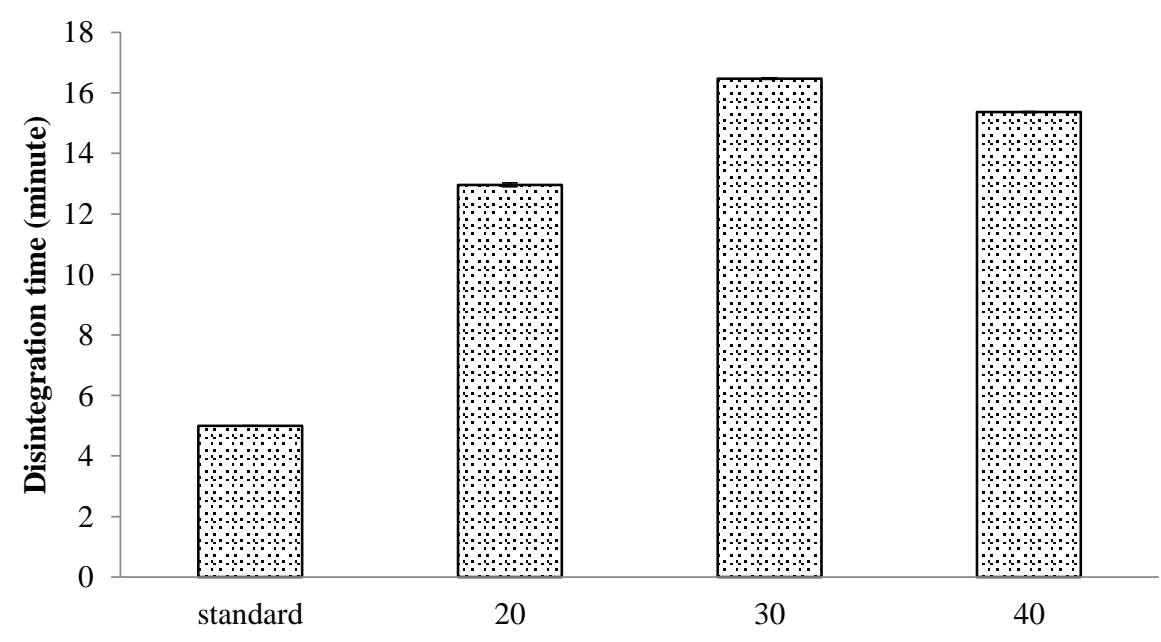

Concentration of maltodextrin coatings (\%)

Fig 4. Disintegration time of probiotic effervescent tablets at several concentrations of maltodextrin coating 
The ratio of citric acid and sodium bicarbonate greatly affects the solubility of the tablet. High fraction of sodium bicarbonate will cause faster solubility. This happens because sodium bicarbonate functions as a crushing agent. When reacting with water it will produce $\mathrm{CO}_{2}$ gas and provide a refreshing effect.
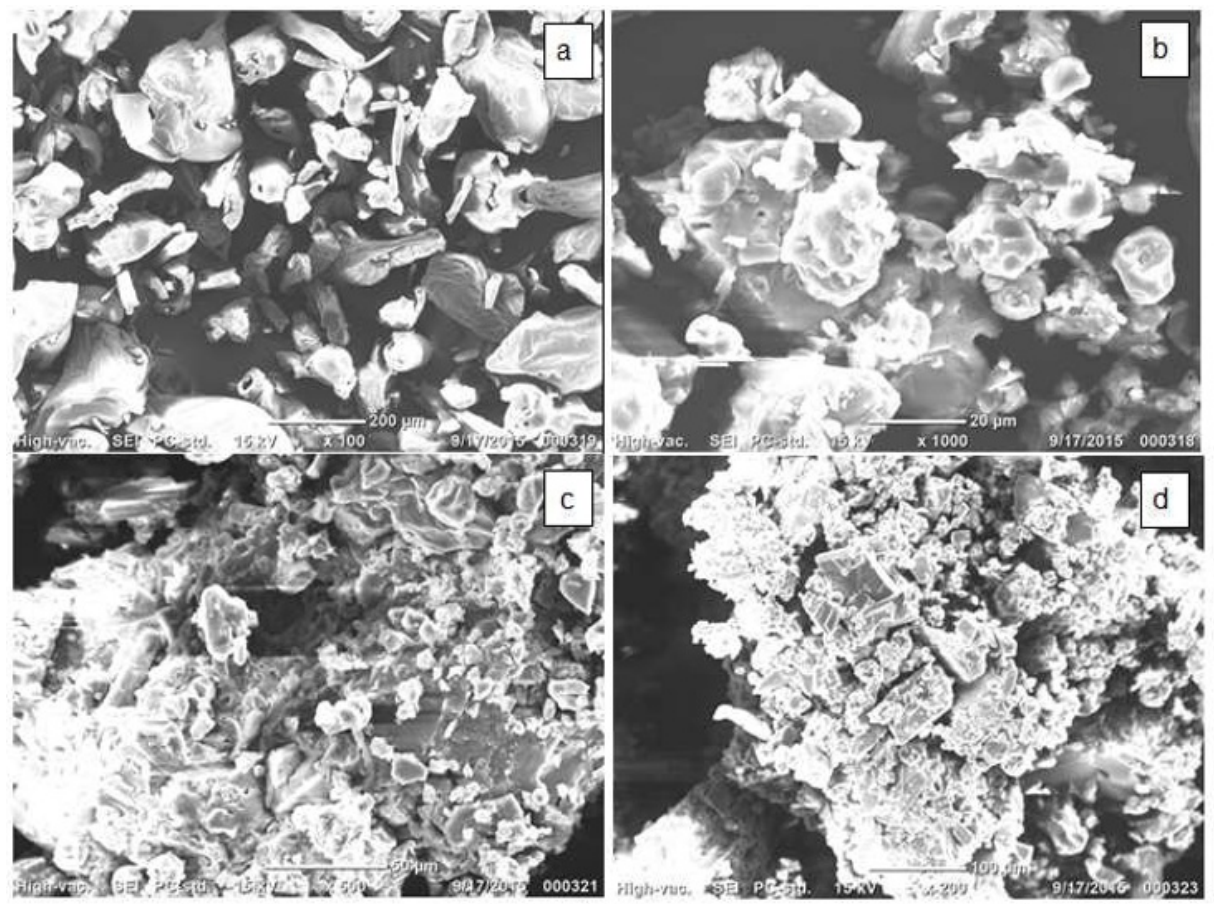

Fig 5. Scanning Electron Microscopy (SEM) of probiotic and effervescent tablets at several concentrations of maltodextrin coating (a: maltodextrin; b: $20 \%$; c: $30 \%$; d: $40 \%$ )

The morphological structure of probiotic and effervescent tablets at several concentrations of maltodextrin coating can be seen from the Scanning Electron Microscopy (SEM) photograph in Figure 5. Higher concentration of the coating will cover the active ingredients. The higher the concentration of the coating, the skin layer is getting better and stronger, so that it can protect the core material well and protect volatile substances when the drying process takes place, which results in the retention of the core material will increase. However, the coating concentration is too high to make the suspension become thick, making it difficult for the atomization process (the release of active ingredients) [24].

\section{Conclusion}

The results showed that the effervescent tablets of probiotics with a concentration of $40 \%$ had an average weight higher than other concentrations at $798.88 \mathrm{mg}$. The effervescent tablets of probiotic with a concentration of $20 \%$ has a lower friability and disintegration time compared to other concentrations of $0.05 \%$ and 12.96 minutes respectively but with a higher level of hardness that is equal to $10.89 \mathrm{~N}$. Overall concentration of $20 \%$ maltodextrin concluded as the best treatment. 


\section{References}

1. Purwanta W. and Firdayati M. Jurnal Teknologi Lingkungan, 3, 1: 61-65. (2002)

2. Waston A. K., Kaspar H., Lategan M. J. and Gibson L. Aquaculture, 274:1-14. (2008)

3. Herlinah and Rachmansyah. Forum Inovasi Teknologi Akuakultur. 161-167. (2010)

4. Atmomarsono M, Muliani and Tampangallo BR. Prosiding Forum Inovasi Teknologi Akuakultur. 269-278. (2010)

5. Pribadi. Probiotik Dalam Budidaya. Kumpulan Majalah Mitra Bahari Edisi 1996-2002. hal 5. (2002)

6. Lindberg N., Engfors H., and Ericsson T. Effervescent Pharmaceutical in Swarbrick, J., Boylan, J.C., (Eds.), Encyclopedia of Pharmaceutical Technology, vol. 5, Mercel Dekker inc., New York, 45- 71. (1992)

7. Lestari A. B. S., and Natalia, L. Optimasi Natrium Sitrat dan Asam Fumarat Sebagai Sumber Asam Dalam Pembuatan Granul Effervescent Ekstrak Temulawak (Curcuma xanthorrhiza Roxb) Secara Granulasi Basah, Majalah Farmasi Indonesia, 18(1), 21-28. (2007)

8. Atjo AS. Artikel Penyuluhan. (2013)

9. Muliani, Nurbaya and Susianingsih E. J. Riset Akuakultur. 6(3) : 457-468. (2011a).

10. Irianto, A. Probiotik Akuakultur. Gadjah Mada University Press. Yogyakarta. Hal 125. (2003)

11. Muliani, Nurbaya and Madeali M. I. J. Riset Akuakultur. 6(1) : 81-92 (2011b)

12. Muliani, Nurbaya dan Atmomarsono A. Jurnal Riset Akuakultur. 1(1) : 73-85. (2006)

13. Teixeira, P., Castro, H., and Kirby, R. Pp. 7. (1995)

14. Ansar, Rahardjo B., Noor Z. and Rochmadi. J. Teknol. dan Industri Pangan, XX (1) : 25-31. (2009)

15. Anwar, K. Sains dan Terapan Kimia. 4(2): 168-178. (2010)

16. Wehling, F. Effervescent Composition Including Stevia.US Patent No. 6,811,793 B2 (2004)

17. Mohrle R., Attwood D., and Banker C. S. Tropical Journal of Pharmaceutical Research, 2(1): 285-286. (1989)

18. Nagashima A. I., Pansiera P. E., Baracat M. M. and Gomez R. J. H. C. Food Sci. and Technol. 33(4): 605-611. (2013)

19. Ansel, H. C., Robinson J. R., and Ericsson T. Journal Pharmaceutical Science, 77(4): 214-217. (1989)

20. Ansar, Rahardjo B., Noor Z. and Suyitno. J. Teknol. dan Industri Pangan, XVII (1) : 23-27. (2006)

21. Anwar, E. Makara, Sains, 6(1):50-54. (2002)

22. Anonym. Farmakope Indonesia, Edisi IV, Departemen Kesehatan Republik Indonesia, Jakarta (1995)

23. Swarbrick, J., Boylan, J. C. Encyclopedia of Pharmaceutical Technology. New York:Marcell Dekker Inc. 404-407 (1992)

24. Sugindro, E. Mardliyati, dan J. Djajadisastra. Pembuatan dan Mikroenkapsulasi Ekstrak Etanol Biji Jinten Hitam Pahit (Nigella sativa Linn.). Majalah Ilmu Kefarmasian. 5 (2): 57-66. (2008). 